\title{
Corn initial vigor in response to humic acids from bovine manure and poultry litter
}

\author{
Desempenho inicial do milho em resposta a ácidos húmicos isolados \\ de esterco bovino e cama de aviário
}

\author{
Raphael Oliveira de Melo $^{1}$; Marihus Altoé Baldotto ${ }^{2 *}$ Lílian Estrela Borges Baldotto²
}

\begin{abstract}
Corn is grown throughout the country, with its yields varying according to the technology investment. Among the technologies that seek to optimize productivity, the focus is on the use of improved seeds, which is associated with the properly integrated management of production factors such as $\mathrm{pH}$ adjustment and soil fertilization, irrigation, pest control and competitors, and more recently, the use of plant growth regulators. Analogous to synthetic growth regulators such as auxins, humic substances in organic matter have a stimulating effect on plants. However, the bioactivity and optimum concentration of humic substances vary with the type of plant and the type of raw materials used for their isolation. This work aimed to study the growth and development of maize in response to the treatment of seeds by different concentrations of humic acids. The treatments involved the application of two sources of humic acid (bovine manure and poultry litter) and five concentrations $\left(0,10,20,30\right.$, and $40 \mathrm{mmol} \mathrm{L}^{-1}$ of C) of humic acid solutions to seeds in a bioassay carried out in a greenhouse. At the end of the experiment (45 days after germination), plants were evaluated biometrically and nutritionally. The results showed a significant increase in the growth and development of shoots and roots, and there was a significant accumulation of $\mathrm{N}$ and $\mathrm{P}$ after the application of humic acid isolated from bovine manure. These effects did not occur with the application of humic acid isolated from poultry litter. Therefore, biostimulation by humic acids isolated from bovine manure showed positive results and was complementary as compared to the effects of other inputs commonly used in the treatment of maize seeds.
\end{abstract}

Key words: Bioactivity, humic substances, soil chemistry and fertility, soil organic matter

\section{Resumo}

O milho é cultivado em todo o país, produzindo quantidades variáveis conforme o investimento em tecnologia. Dentre essas tecnologias, destaca-se o uso de sementes melhoradas, associadas com adequado manejo integrado dos fatores de produção, tais como a correção e fertilização dos solos, a irrigação, o controle fitossanitário e de competidores e, mais recentemente, o uso de biorreguladores, buscando otimizar a produtividade. De forma análoga aos reguladores de crescimento sintéticos, como as auxinas, as substâncias húmicas da matéria orgânica apresentam um efeito estimulante em plantas. Contudo, a bioatividade e a concentração ótima das substâncias húmicas variam de acordo com as espécies vegetais e com matérias primas das quais elas foram isoladas. Por essas razões, este trabalho teve como objetivo estudar o crescimento e desenvolvimento do milho, em resposta à aplicação de diferentes concentrações de ácidos húmicos, via tratamento de sementes. Os tratamentos constituíramse de duas fontes de ácidos húmicos (esterco bovino e cama de aviário) utilizando cinco concentrações

\footnotetext{
${ }^{1}$ Discente do Curso de Graduação em Agronomia, Campus de Florestal, Universidade Federal de Viçosa, UFV, Florestal, MG, Brasil. E-mail: raphael.o.melo@ufv.br

${ }^{2}$ Profs. Permanente, Campus de Florestal, UFV, Florestal, MG, Brasil. E-mail: marihus@ufv.br; lilian.estrela@ufv.br

* Author for correspondence
} 
$\left(0,10,20,30\right.$ e $40 \mathrm{mmol} \mathrm{L}^{-1}$ de C) das respectivas soluções, aplicado via tratamentos de sementes em um bioensaio conduzido em casa de vegetação. Ao final do experimento (45 dias após a germinação), as plantas foram avaliadas biometricamente e nutricionalmente. Os resultados mostraram incrementos significativos no crescimento e desenvolvimento da parte aérea e do sistema radicular, e acumulo significativo dos nutrientes $\mathrm{N}$ e $\mathrm{P}$ com a aplicação de ácidos húmicos isolados de esterco bovino, sendo que os mesmos não ocorreram com a aplicação de ácidos húmicos isolados de cama de aviário. Assim o uso de bioestimulantes à base de ácidos húmicos isolados de esterco bovino é positivo e complementar comparativamente aos insumos geralmente usados no tratamento de sementes de milho.

Palavras-chave: Bioativitividade, matéria orgânica do solo, química e fertilidade do solo, substâncias húmicas

\section{Introduction}

The national corn production is quite technologically advanced, instigating an increase in yields in recent years (CONAB, 2013). Although this improvement has been witnessed in different regions of Brazil, the tendency has not been homogeneous throughout the country (CRUZ et al., 2008). One of the factors regulating this heterogeneity in yield in Brazil is the difference in the level of investment in agricultural technology. Among the technologies available for corn production, it is worth to mention the use of improved seeds in combination with the optimization of other factors affecting production, i.e., integrated nutrition management, plant protection, and irrigation. Recently developed technologies incorporate the use of plant growth regulators to stimulate plant metabolism and increase the efficiency of light, water and nutrients use (BALDOTTO et al., 2012a; BALDOTTO; BALDOTTO, 2013). However, the effect of this technology on corn yield has not been studied extensively.

Several materials can be used as biostimulants, including humic substances, which are composed of fulvic (FA) and humic acids (HA), the main components of organic matter in soil and organic compounds (GUERRA et al., 2008). Piccolo (2001) postulated that, unlike macromolecules of high molecular weight, humic acids are formed by a series of several structural units of relatively low molecular weight, which are stabilized by weak interactions, mainly hydrophobic interactions in close to neutral $\mathrm{pH}$, and by $\mathrm{H}^{+}$bonds in acidic solutions. Therefore, in a solution, humic acids can release small units from their conformation in response to environmental changes such as during the release of exudates from plants.

The physiological effect of humic acids is related, at least in part, to the presence of chemical structures similar to plant hormones. Assessing the potential of humic acids isolated from different sources of organic matter on growth and development of plants of agricultural interest has been investigated in several studies carried out in Brazil and worldwide (BALDOTTO et al., 2009; BALDOTTO; BALDOTTO, 2013; CANELLAS; FAÇANHA, 2004; CHEN et al., 2004; FAÇANHA et al., 2002).

Humic acids have a positive effect on seed germination, root development, and growth, thus modulating total plant biomass. The effect of these substances was reported to be analogous to auxins in stimulating and accelerating the growth of roots and aerial parts (BALDOTTO et al., 2012a; BALDOTTO; BALDOTTO, 2013). For most crops, greater response of plants to humic and fulvic acids occurs at concentrations between 10 and $20 \mathrm{mmol}$ $\mathrm{L}^{-1}$ of $\mathrm{C}$, which are used, for instance, for treatment of seeds, stem cuttings, and in post-planting sprays. At higher concentrations, the effect stabilizes and tends to decrease, sometimes being even detrimental when compared to no applications (BALDOTTO et al., 2009; BALDOTTO et al., 2012a; BALDOTTO; BALDOTTO, 2013; CANELLAS et al., 2006; 
SILVA et al., 2011). Nardi (2002) and Baldotto (2011) reviewed about the effects of humic substances on diferent plants. Eyheraguibel et al. (2008) observed that the percentage or rate of seed germination in corn was not influenced by the presence of humic substances, although there was an increase in the root length of seedlings from treated seeds. He also observed positive effects on the production of dry matter in roots as well as branches and leaves in plants cultivated in a nutritive solution containing humic substances.

Considering that the nature of these substances is complex and not well studied, it is essential to further study their effects and determine their optimal concentrations for different cultivated plants, especially when comparing the different organic compounds from which they are isolated.

The aim of this study was to assess the initial vigor and nutritional status of corn plants as a function of seed treatments with solutions with increasing concentrations of humic acids, which were isolated from cattle manure and poultry litter, through a bioassay carried out in a greenhouse.

\section{Materials and Methods}

The experiment was carried out at Florestal Campus of the Federal University of Viçosa (CAFUFV), Florestal, Minas Gerais State, Brazil, located at coordinates $19^{\circ} 52^{\prime} 16.3^{\prime \prime} \mathrm{S}$ and $44^{\circ} 25^{\prime} 26.1^{\prime \prime} \mathrm{W}$, at an altitude of approximately $750 \mathrm{~m}$, during the first semester of 2012. Humic acids were isolated from organic compounds obtained from cattle manure and poultry litter (BALDOTTO et al., 2011), provided by a CAF-UFV stable and Granja Brasília $^{\circledR}$, respectively. Zootechnical management of both providers follows the recommendations of EMBRAPA (2001) and EMBRAPA (2011) for organic residuals from cattle and poultry, respectively.

The experimental setup $(5 \times 2)$ consists of following factors: five concentrations $(0,10,20,30$, and $40 \mathrm{mmol} \mathrm{L}^{-1}$ of C) of humic acids isolated from cattle manure (HAC) or poultry litter (HAP). Humic acids isolated from poultry litter and cattle manure were previously isolated and assessed by Baldotto et al. (2012b) and Baldotto and Baldotto (2013). The experiment was completely randomized, with five repetitions and a total of 50 experimental units.

Corn seeds (Zea mays L.), variety AG1051, were immersed for 16 hours in their respective treatment solutions with increasing concentrations of humic acids. For these procedures, seeds were placed in plastic pots with an amount of solution necessary to keep the seeds submerged. Two 2- $\mathrm{dm}^{3}$ flower pots were used; these were filled with a substrate with equal proportions of sand, soil (subsuperficial horizon of a common dystrophic red latosol), and organic compounds (prepared from cattle manure, according to a method described by Kiehl (2004). Chemical analysis of the substrate, utilizing the normal measurements recommended for the State of Minas Gerais, according to Ribeiro et al. (1999), showed the following composition: $\mathrm{pH} 5.3 ; \mathrm{P}=120$ $\mathrm{mg} \mathrm{dm}{ }^{-3} ; \mathrm{K}=118 \mathrm{mg} \mathrm{dm}^{-3} ; \mathrm{Ca}^{2+}=22.9 \mathrm{cmol}_{\mathrm{c}} \mathrm{dm}^{-3}$; $\mathrm{Mg}^{2+}=1.7 \mathrm{cmol}_{\mathrm{c}} \mathrm{dm}^{-3} ; \mathrm{Al}^{3+}=0.4 \mathrm{cmol}_{\mathrm{c}} \mathrm{dm}^{-3} ; \mathrm{H}+\mathrm{Al}$ $=3.80 \mathrm{cmol}_{\mathrm{c}} \mathrm{dm}^{-3} ; \mathrm{SB}=24.90 \mathrm{cmol}_{\mathrm{c}} \mathrm{dm}^{-3} ; \mathrm{t}=25.3$ $\mathrm{cmol}_{\mathrm{c}} \mathrm{dm}^{-3} ; \mathrm{T}=28.70 \mathrm{cmol}_{\mathrm{c}} \mathrm{dm}^{-3} ; \mathrm{V}=87 \%$ and $\mathrm{m}=$ $2 \%$; MOS $=2.6$ dag $\mathrm{kg}^{-1}$; and P-rem $=58.7 \mathrm{mg} \mathrm{L}^{-1}$.

Five seeds were sown per pot and after the seedlings emerged, three were removed and the remaining two were used for the experiment. The pots were kept in a greenhouse and irrigated daily for 45 days.

At the end of the experiment, the following variables were determined: plant height $(\mathrm{H})$; number of leaves (NL); width of the middle part of the largest leaf (LLW); length of the largest leaf (LLL), and stem diameter (SD). The seedlings were collected by cutting the plants close to the substrate, and the fresh matter of the aerial parts was determined (FMAP). Plant roots were separated from the substrate and washed under running water to determine the fresh root matter (FRM). Both 
aerial parts and root systems were placed in paper bags and kept in a forced-air oven, at $60^{\circ} \mathrm{C}$ for 72 hours, to dehydrate plant matter until reaching a constant weight and to determine the dry matter of both the aerial part (DMAP) and root system (DMR).

After drying, corn leaves were ground in a Wiley mill coupled to $0.25-\mathrm{mm}$ (60 mesh) sieves. The sieved material was digested with sulfuric acid combined with hydrogen peroxide, and the total N, $\mathrm{P}$, and $\mathrm{K}$ contents were determined. Total $\mathrm{N}$ content was determined using the Kjeldahl method; total $\mathrm{P}$ content was determined by molecular absorption spectrophotometry (colorimetry) at a wavelength of $725 \mathrm{~nm}$, after the solution was treated with vitamin $\mathrm{C}$ and ammonium molybdate. Total $\mathrm{K}$ content was determined by flame photometry (EMBRAPA, 1979).

The results were subjected to analysis of variance, the qualitative variables were separated into average contrasts according to Alvarez and Alvarez (2006), and F test was applied with 5\% probability to the separated factors. To analyze the quantitative effects, regression equations were adjusted between the means of the studied biometric and nutritional variables and the concentrations of HA, when the values of the determination coefficients were greater or equal to 0.60. Regression equations were used to determine the concentrations of humic acids extracted from cattle manure and poultry litter that allow maximum accumulation of dry matter in plants aerial parts. After obtaining the values of the maximum efficiency concentrations for each of the humic acids, the values for other variables were determined in the same condition (BALDOTTO; BALDOTTO, 2013). The difference between the values of all variables at the maximum accumulation of dry matter of the aerial part (maximum physical efficiency) and the values from the controls was assessed by Tukey's honest significant difference test $\left(\mathrm{HSD}_{\text {Tukey }}\right)$ at a significance level of $5 \%$. This served in calculating the effects, which were also presented as percentages.

\section{Results}

In general, the results showed that the initial vigor of corn seedlings was positively affected by the treatment of seeds with humic acids isolated from cattle manure compared to the treatment with humic acids isolated from poultry litter, and both had greater effect than the control (Tables 1 and 2).

Once the mean values were obtained for growth characteristics and nutritional status of corn plants in response to the seed treatment with increasing concentrations of humic acids from cattle manure and poultry litter, the average contrasts (Tables 1 and 2) were calculated according to Alvarez and Alvarez (2006). The average contrasts represent the difference, in real magnitude, between the averages of the treatments extrapolated from biometric and nutrient characteristics of corn plants. These values indicate significant differences in the initial growth and nutrient status of corn in response to humic acids isolated from cattle manure when compared to that in response to humic acids isolated from poultry litter.

The average contrasts showed that for all characteristics, except the number of leaves, humic acids isolated from cattle manure had a greater effect compared to humic acids isolated from poultry litter. Statistically significant difference at $5 \%$ level was observed in the following variables: height, stem diameter, length of the largest leaf, fresh matter of aerial parts and root system, dry matter of aerial parts, root system, and $\mathrm{P}$ content (Table 1 and 2). 
Table 1. Average contrasts and variation coefficients (VC\%) for height $(\mathrm{H})$, number of leaves $(\mathrm{NL})$, width of the largest leaf (LLW), length of the largest leaf (LLL), stem diameter (SD), fresh matter of the aerial part (FMAP), dry matter of the aerial part (DMAP), fresh root matter (FRM), and dry root matter (DRM), in response to increasing concentrations $\left(0,10,20,30,40 \mathrm{mmol} \mathrm{L}^{-1}\right.$ of $\left.\mathrm{C}\right)$ of humic acids isolated from cattle manure (HAC) and poultry litter (HAP).

\begin{tabular}{|c|c|c|c|c|c|c|c|c|c|}
\hline Treatment & $\mathbf{H}$ & NL & LLW & LLL & SD & FMAP & FRM & DMAP & DRM \\
\hline & $\mathrm{cm}$ & & ---- & ---cm---- & ------ & -------- & -- g per & lant ------ & ------ \\
\hline HAC (0) & 41.68 & 6.4 & 2.78 & 53.70 & 0.51 & 16.50 & 6.61 & 1.23 & 0.49 \\
\hline HAC (10) & 52.69 & 6.2 & 3.22 & 57.50 & 0.53 & 19.07 & 8.92 & 1.84 & 0.69 \\
\hline HAC (20) & 45.42 & 5.8 & 3.33 & 59.50 & 0.58 & 19.23 & 9.23 & 2.08 & 0.79 \\
\hline HAC (30) & 41.42 & 6.1 & 2.76 & 54.40 & 0.48 & 18.34 & 9.58 & 1.67 & 1.19 \\
\hline HAC (40) & 44.78 & 6.4 & 3.09 & 59.10 & 0.65 & 16.46 & 9.77 & 1.84 & 1.26 \\
\hline VC (\%) & 14.54 & 9.4 & 12.69 & 8.73 & 18.72 & 26.08 & 26.38 & 22.39 & 46.09 \\
\hline HAP (0) & 40.29 & 6.2 & 2.57 & 56.05 & 0.54 & 17.33 & 6.70 & 1.48 & 0.69 \\
\hline HAP (10) & 42.62 & 6.3 & 3.23 & 57.65 & 0.57 & 16.57 & 8.34 & 1.59 & 0.80 \\
\hline HAP (20) & 36.58 & 6.2 & 2.94 & 55.40 & 0.49 & 16.29 & 7.65 & 1.51 & 0.74 \\
\hline HAP (30) & 40.16 & 5.8 & 2.40 & 53.65 & 0.51 & 12.24 & 7.06 & 1.58 & 0.64 \\
\hline $\operatorname{HAP}(40)$ & 35.22 & 6.2 & 2.66 & 53.20 & 0.52 & 15.33 & 8.95 & 1.36 & 1.01 \\
\hline $\mathrm{VC}(\%)$ & 18.04 & 10.6 & 22.95 & 14.98 & 23.58 & 39.03 & 31.95 & 41.21 & 45.77 \\
\hline $\begin{array}{l}\text { Contrast } \\
\text { HAC vs. HAP }\end{array}$ & $-6.04 * *$ & -0.17 & $-0.08 * *$ & $-5.01 * *$ & $-0.03 * *$ & $-3.99 * *$ & $-1.47 * *$ & $-0.60 * *$ & $-0.37 * *$ \\
\hline
\end{tabular}

F Test: significant $* * 5 \%$ probability.

Table 2. Average contrasts and variation coefficients ( $\mathrm{VC} \%$ ) for macronutrient levels and the contents of nitrogen $(\mathrm{N})$, phosphorus $(\mathrm{P})$, and potassium $(\mathrm{K})$ in corn, in response to increasing concentrations $\left(0,10,20,30,40 \mathrm{mmol} \mathrm{L}^{-1}\right.$ of $\left.\mathrm{C}\right)$ of humic acids isolated from cattle manure (HAC) and poultry litter (HAP).

\begin{tabular}{|c|c|c|c|c|c|c|}
\hline \multirow{2}{*}{ Treatments } & \multicolumn{3}{|c|}{ Levels } & \multicolumn{3}{|c|}{ Content } \\
\hline & $\mathbf{N}$ & $\mathbf{P}$ & $\mathbf{K}$ & $\mathbf{N}$ & $\mathbf{P}$ & $\mathbf{K}$ \\
\hline & \multicolumn{3}{|c|}{-----------mg per plant------------ } & \multicolumn{3}{|c|}{------------'mg per plant------------ } \\
\hline HAC (0) & 0.44 & 0.12 & 4.43 & 39.15 & 1.45 & 54.43 \\
\hline HAC (10) & 0.33 & 0.11 & 4.00 & 45.37 & 2.15 & 72.98 \\
\hline HAC (20) & 0.35 & 0.11 & 3.70 & 60.44 & 2.45 & 76.64 \\
\hline HAC (30) & 0.37 & 0.11 & 3.54 & 51.87 & 1.85 & 52.27 \\
\hline HAC (40) & 0.40 & 0.10 & 3.33 & 50.60 & 1.93 & 61.91 \\
\hline $\mathrm{VC}(\%)$ & 11.48 & 5.98 & 7.04 & 41.59 & 22.12 & 23.27 \\
\hline $\mathrm{HAP}(0)$ & 0.45 & 0.11 & 4.26 & 52.88 & 1.68 & 63.73 \\
\hline HAP (10) & 0.41 & 0.11 & 4.29 & 52.27 & 1.84 & 68.39 \\
\hline HAP (20) & 0.43 & 0.11 & 3.87 & 43.6 & 1.72 & 59.93 \\
\hline HAP (30) & 0.38 & 0.11 & 4.05 & 59.75 & 1.79 & 64.67 \\
\hline $\operatorname{HAP}(40)$ & 0.41 & 0.10 & 4.54 & 47.38 & 1.49 & 62.00 \\
\hline VC (\%) & 7.65 & 4.34 & 6.84 & 33.57 & 40.70 & 43.12 \\
\hline HAC vs. HAP & 0.03 & 0.00 & 0.85 & -5.09 & $-0.62 * *$ & -11.5 \\
\hline
\end{tabular}

F Test: significant $* * 5 \%$ probability. 
Regression equations were adjusted for biometric and nutritional variables of corn plants in response to increasing concentrations of humic acids derived from cattle manure and poultry litter in the treatment of seeds (Table 3 and 4). In general, a quadratic response was observed for characteristics related to the growth and nutritional status of the plants, i.e., the values increase until reaching a plateau and subsequently decrease in response to the application of increasing concentrations of HA. We did not adjust the regression equations for several variables because determination coefficient was less than $0.60\left(\mathrm{R}^{2}<\right.$ $0.60)$. Instead, we estimated the average data of the response curve $(\hat{\mathrm{y}}=\overline{\mathrm{y}})$.

Table 3. Regression equations for the growth variables of height $(\mathrm{H})(\mathrm{cm})$, number of leaves $(\mathrm{NL})$, width of the largest leaf (LLW) $(\mathrm{cm})$, length of the largest leaf (LLL) $(\mathrm{cm})$, stem diameter $(\mathrm{SD})(\mathrm{cm})$, fresh matter of aerial part (FMAP) (g per plant), dry matter of aerial part (DMAP) (g per plant), fresh root matter (FRM) (g per plant), and dry root matter (DRM) (g per plant) of plants treated with humic acids isolated from cattle manure (HAC) and poultry litter (HAP).

\begin{tabular}{|c|c|c|c|}
\hline Variable & Splitting & Equation & $\mathbf{R}^{2}$ \\
\hline $\mathrm{H}$ & $\begin{array}{l}\text { Concentration of HAC } \\
\text { Concentration of HAP }\end{array}$ & $\begin{array}{l}\hat{y}=\bar{y}=45.19 \\
\hat{y}=\bar{y}=38.98\end{array}$ & \\
\hline NL & $\begin{array}{l}\text { Concentration of HAC } \\
\text { Concentration of HAP }\end{array}$ & $\begin{array}{l}\hat{y}=6.442-0.049 x+0.001 x^{2} \\
\hat{y}=\bar{y}=6.18\end{array}$ & 0.836 \\
\hline LLW & $\begin{array}{l}\text { Concentration of HAC } \\
\text { Concentration of HAP }\end{array}$ & $\begin{array}{l}\hat{y}=\bar{y}=3.04 \\
\hat{y}=\bar{y}=2.76\end{array}$ & \\
\hline LLL & $\begin{array}{l}\text { Concentration of HAC } \\
\text { Concentration of HAP }\end{array}$ & $\begin{array}{l}\hat{y}=\bar{y}=56.84 \\
\hat{y}=56.61+0.00 x-0.002 x^{2}\end{array}$ & 0.784 \\
\hline SD & $\begin{array}{l}\text { Concentration of HAC } \\
\text { Concentration of HAP }\end{array}$ & $\begin{array}{l}\hat{y}=\bar{y}=0.55 \\
\hat{y}=\bar{y}=0.52\end{array}$ & \\
\hline FMAP & $\begin{array}{l}\text { Concentration of HAC } \\
\text { Concentration of HAP }\end{array}$ & $\begin{array}{l}\hat{y}=16.661+0.2762 x-0.0071 x^{2} \\
\hat{y}=\bar{y}=15.51\end{array}$ & 0.969 \\
\hline FRM & $\begin{array}{l}\text { Concentration of HAC } \\
\text { Concentration of HAP }\end{array}$ & $\begin{array}{l}\hat{y}=6.826+0.189 x-0.003 x^{2} \\
\hat{y}=\bar{y}=7.74\end{array}$ & 0.937 \\
\hline DMAP & $\begin{array}{l}\text { Concentration of HAC } \\
\text { Concentration of HAP }\end{array}$ & $\begin{array}{l}\hat{y}=1.3034+0.0542 x-0.0011 x^{2} \\
\hat{y}=1.4811+0.012 x-0.0004 x^{2}\end{array}$ & $\begin{array}{l}0.693 \\
0.719\end{array}$ \\
\hline DRM & $\begin{array}{l}\text { Concentration of HAC } \\
\text { Concentration of HAP }\end{array}$ & $\begin{array}{l}\hat{y}=0.481+0.019 x+0.00003 x^{2} \\
\hat{y}=\bar{y}=0.78\end{array}$ & 0.953 \\
\hline
\end{tabular}


Table 4. Regression equations for levels and content of macronutrients of treated corn plants. Nitrogen level (NL), phosphorus level (PL), potassium level (KL), nitrogen content (NC), phosphorus content (PC), and potassium content (KC) of plants in response to humic acids isolated from cattle manure (HAC) and humic acids from poultry litter (HAP).

\begin{tabular}{cllc}
\hline Variable & \multicolumn{1}{c}{ Splitting } & \multicolumn{1}{c}{ Equation } & $\mathbf{R}^{2}$ \\
\hline \multirow{2}{*}{ NL } & Concentration of AHE & $\hat{y}=0.406-0.008 x+0.000 \mathrm{x}^{2}$ & 0.770 \\
& Concentration of HAP & $\hat{y}=\bar{y}=0.41$ & \\
PL & Concentration of HAC & $\hat{y}=0.114+0.000 x-0.000007 \mathrm{x}^{2}$ & 0.966 \\
& Concentration of HAP & $\hat{y}=0.118+0.000 \mathrm{x}-0.00001 \mathrm{x}^{2}$ & 0.994 \\
$\mathrm{KL}$ & Concentration of HAC & $\hat{\mathrm{y}}=4.416-0.043 \mathrm{x}+0.000001 \mathrm{x}^{2}$ & 0.994 \\
& Concentration of HAP & $\hat{\mathrm{y}}=4.359-0.039 \mathrm{x}+0.001 \mathrm{x}^{2}$ & 0.667 \\
$\mathrm{NC}$ & Concentration of HAC & $\hat{\mathrm{y}}=38.08+1.397 \mathrm{x}-0.027 \mathrm{x}^{2}$ & 0.769 \\
& Concentration of HAP & $\hat{\mathrm{y}}=\overline{\mathrm{y}}=51.18$ & 0.675 \\
$\mathrm{NC}$ & Concentration of HAC & $\hat{\mathrm{y}}=1.528+0.067 \mathrm{x}-0.001 \mathrm{x}^{2}$ & 0.779 \\
& Concentration of HAP & $\hat{\mathrm{y}}=1.685+0.016 \mathrm{x}-0.000001 \mathrm{x}^{2}$ & \\
\hline
\end{tabular}

By means of regression equations, the concentrations that resulted in the maximum accumulation of dry matter were calculated in corn aerial parts treated with humic acids extracted from cattle manure and poultry litter. The values were $23.40 \mathrm{mmol} \mathrm{L}^{-1}$ of $\mathrm{C}$ for humic acids extracted from cattle manure and $14.80 \mathrm{mmol} \mathrm{L}^{-1}$ of $\mathrm{C}$ for humic acids isolated from poultry litter. Under these conditions, we observed an increase of $45 \%$ and $16 \%$ in dry mass of aerial parts compared to the controls for humic acids extracted from cattle manure and poultry litter, respectively.

Using the regression equations shown in Tables 3 and 4, the values corresponding to the concentrations of maximum physical efficiency of MSPA were substituted for the independent variable (X), and the data for the remaining observed variables were calculated under this condition (Table 5). For maximum physical efficiency (MPE), according to the growth characteristics of the plant, it was observed that the application of humic acids isolated from cattle manure to corn seeds increased all growth variables, except the number of leaves. Thus, significant increase was observed for accumulation of fresh root matter, dry root matter and dry matter of aerial part, whereas significant decrease was detected in the number of leaves. The application of humic acids isolated from poultry litter resulted in significant changes in studied variables. Regarding the nutritional status, the application of humic acids from cattle manure showed a significant increase in the contents of $\mathrm{N}$ and P. When using humic acids from poultry litter no significant accumulations of these nutrients was observed (Table 5). It was noticed that the contents of the nutrients were adequate to assess their absorption, whereas the nutritional levels suffered the effects of the dilution.

\section{Discussion}

Significant, but different, effects were observed in the vigor of plants and accumulation of nutrients, when treated with humic acids derived from two different sources, cattle manure and poultry litter (Table 1 and 2). The results showed that the application of humic acids from cattle manure positively affects most of the growth characteristics 
and the absorption of $\mathrm{N}, \mathrm{P}$, and $\mathrm{K}$ by corn seedlings, when compared to humic acids isolated from poultry litter. The data are consistent with those of other studies that show that humic substances isolated from different sources have different impact on plant vigor (SILVA et al., 1998a, b; FAÇANHA et al., 2002; EYHERAGUIBEL et al., 2008; BALDOTTO; BALDOTTO, 2013).

The results of this study indicate that new technological opportunities may be developed based on plant stimulants that increase corn yield. According to Silva et al. (2008), there is a higher demand for improved seeds, associated with the treatment with fungicides, insecticides, and recently biostimulants.

The treatment of seeds with humic acids extracted from cattle manure ensured significant increase in the initial growth of the aerial and root parts of the corn seedlings. An increase in the content of $\mathrm{P}$ was observed compared to that in the control. These results are consistent with those of Eyheraguibel et al. (2008), who observed an increase in the root length and improved nutritional status of corn seedlings when treated with humic acids. Positive effects were also observed on the production of dry plant mass in roots, as well as in branches and leaves. This increase in dry mass was accompanied by greater water consumption and nutrient absorption, indicative of biostimulation.

According to Almeida et al. (1998), the increase in plant dry mass is reflected by the crop yield; plants with greater initial growth and dry matter accumulation can better utilize solar radiation, which is available at the beginning of the cycle, and can enhance the availability of carbohydrates for better vigor. This notion is supported by the fact that corn is a species with C4 metabolism, which tends to better express its genetic potential through the efficient use of solar radiation. Therefore, an increase in the growth of biostimulated plants results in better photosynthetic efficiency.

Table 5. Values of the biometric characteristics: height (H), number of leaves (NL), width of the largest leaf (LLW), length of the largest leaf (LLL), stem diameter (SD), fresh matter of aerial part (FMAP), dry matter of aerial part (DMAP), fresh root matter (FRM), dry root matter (DRM), and those of nutritional status: nitrogen level (NL), phosphorus level (PL), potassium level (KL), nitrogen content $(\mathrm{NC})$, phosphorus content (PC), potassium content (KC) of corn plants for the maximum physical efficiency (Concentration of MPE $=23.40$ and $14.25 \mathrm{mmol} \mathrm{L}^{-1} \mathrm{C}_{\text {of }}$ HA) of humic acids isolated from cattle manure (HAC) and poultry litter (HAP), obtained from the dry matter of aerial part (DMAP).

\begin{tabular}{|c|c|c|c|c|c|c|}
\hline Variable & HA & $\begin{array}{r}\text { Average } \\
\text { control }\end{array}$ & $\begin{array}{l}\text { MPE } \\
\text { value }\end{array}$ & Difference & $\begin{array}{r}\text { HSD }_{\text {Tukey }} \\
(\mathbf{5 \%})\end{array}$ & $\begin{array}{r}\text { ontinue ... } \\
\text { Effect }^{(1)} \\
(\%)\end{array}$ \\
\hline \multirow[t]{2}{*}{$\mathrm{H}(\mathrm{cm})$} & HAC & 41.68 & 45.19 & 3.51 & 5.39 & 8.42 \\
\hline & HAP & 40.29 & 38.98 & -1.31 & 5.39 & -3.36 \\
\hline \multirow[t]{2}{*}{ NL } & HAC & 6.40 & 5.90 & $-0.50 *$ & 0.49 & -7.80 \\
\hline & HAP & 6.20 & 6.18 & -0.02 & 0.49 & -0.32 \\
\hline \multirow[t]{2}{*}{ LLW (cm) } & HAC & 2.78 & 3.04 & 0.26 & 0.42 & 9.35 \\
\hline & HAP & 2.57 & 2.76 & 0.19 & 0.42 & 7.39 \\
\hline \multirow[t]{2}{*}{ LLL (cm) } & HAC & 53.70 & 56.84 & 3.14 & 5.69 & 5.85 \\
\hline & HAP & 56.05 & 56.55 & 0.50 & 5.69 & 0.90 \\
\hline \multirow[t]{2}{*}{$\mathrm{SD}(\mathrm{cm})$} & HAC & 0.51 & 0.55 & 0.04 & 0.09 & 7.84 \\
\hline & HAP & 0.54 & 0.52 & -0.02 & 0.09 & -3.85 \\
\hline \multirow[t]{2}{*}{ FMAP(g) } & HAC & 16.50 & 19.23 & 2.73 & 5.02 & 16.55 \\
\hline & HAP & 17.33 & 15.51 & -1.82 & 5.02 & -11.73 \\
\hline
\end{tabular}




\begin{tabular}{|c|c|c|c|c|c|c|}
\hline & & & & & & Continuation \\
\hline \multirow[t]{2}{*}{ FRM (g) } & HAC & 6.61 & 9.26 & $2.65^{*}$ & 2.25 & 40.09 \\
\hline & HAP & 6.70 & 7.74 & 1.04 & 2.25 & 15.52 \\
\hline \multirow[t]{2}{*}{$\operatorname{DMAP}(\mathrm{g})$} & HAC & 1.36 & 1.97 & $0.61 *$ & 0.41 & 44.85 \\
\hline & HAP & 1.36 & 1.58 & 0.22 & 0.41 & 16.18 \\
\hline \multirow[t]{2}{*}{ DRM (g) } & HAC & 0.49 & 0.94 & $0.45^{*}$ & 0.35 & 92.25 \\
\hline & HAP & 0.69 & 0.78 & 0.09 & 0.35 & 13.04 \\
\hline \multirow[t]{2}{*}{ NL (mg per plant) } & HAC & 0.44 & 0.21 & $-0.23^{*}$ & 0.02 & -47.42 \\
\hline & HAP & 0.45 & 0.41 & 0.04 & 0.02 & -8.89 \\
\hline \multirow[t]{2}{*}{ PL (mg per plant) } & HAC & 0.12 & 0.11 & $-0.10 *$ & 0.002 & -8.33 \\
\hline & HAP & 0.11 & 0.12 & $0.10^{*}$ & 0.002 & 9.09 \\
\hline \multirow[t]{2}{*}{ KL (mg per plant) } & HAC & 4.43 & 3.50 & $-0.93 *$ & 0.07 & -22.51 \\
\hline & HAP & 4.26 & 3.99 & $-0.27 *$ & 0.07 & -6.33 \\
\hline \multirow[t]{2}{*}{ NC (mg per plant) } & HAC & 39.15 & 55.98 & $16.83^{*}$ & 15.91 & 43.00 \\
\hline & HAP & 52.88 & 51.18 & -1.70 & 15.91 & -3.36 \\
\hline \multirow[t]{2}{*}{ PC (mg per plant) } & HAC & 1.45 & 2.27 & $0.82 *$ & 0.46 & 56.55 \\
\hline & HAP & 1.68 & 1.91 & 0.23 & 0.46 & 13.68 \\
\hline \multirow[t]{2}{*}{$\mathrm{KC}$ (mg per plant) } & HAC & 55.34 & 65.05 & 9.71 & 17.66 & 17.55 \\
\hline & HAP & 63.73 & 63.75 & 0.02 & 17.66 & 0.03 \\
\hline
\end{tabular}

(1) Percentage Effect: $100\left(y_{1}-y_{2}\right) / y_{2}$, where $y_{1}$ is the average of the treatment of the higher value and $y_{2}$ the average of the treatment of the lower value.

*: significant at $5 \%$ by Tukey's Honestly Significant Difference test.

Similarly, good initial development of the root system improves the yield due to the larger volume of soil they explore, which enables the crops to better tolerate stress, particularly hydric perturbations, and facilitates a higher capacity for nutrients absorption (directly increasing the mechanism of root interception and indirectly the mass flow and diffusion). According to Façanha et al. (2002), the positive effect of humic acids on the development of the root system may be attributed to its stimulating effect, which is similar to that of plant hormones, as these authors confirmed that humic acids are able to increase the activity of ATPases, which favor root expansion.

The higher development of corn seedlings may be associated with the increased absorption of nutrients due to the influence of humic substances on cell membrane permeability through the action of humic substances and the activation of $\mathrm{H}^{+}$ATPase in the plasma membrane (CANELLAS; SANTOS, 2005). As it was observed in this study, there was a significant increase in the content of $\mathrm{N}$ and $\mathrm{P}$ (Table 5) in plants with faster growth rates and treated with humic acids isolated from cattle manure. These results agree with the data obtained by Eyheraguibel et al. (2008), who observed that corn seedlings under treatment with humic acids in nutritive solution accumulated significant amounts of nutrients.

In this study, the nutrients content in plant tissue was significantly lower than in the control when humic acids from both sources were applied (Table 5). The data seem to be related to the effect of nutrient dilution in the leaves, resulting from the relationship between high growth rates relative to dry matter and nutrient absorption, which was observed in this study (Table 5). According to Bataglia et al. (1996), during the initial phase of the growth period, the rate of nutrient absorption is high, because of which the concentrations of these nutrients in tissues are high as well. As it develops and accumulates dry matter, a dilution 
of the nutrients occurs, causing a decrease in the nutrient content in the tissue. In keeping with this notion, the content of the nutrients presented in this study did not suffer the dilution effects and are the most appropriate to estimate nutrients absorption and accumulation, confirming the effect of humic acids on plant nutrition.

It was found that the response curves to increasing concentrations of humic acids presented a quadratic variation, confirming the "concentrationdependent" effect of humic acids on plant development (BALDOTTO; BALDOTTO, 2013). The results show that the empirical application of humic acids, without knowing the concentration that provides the highest efficiency, may not cause an effect or it may even induce a negative effect, thus proving the necessity to determine the optimal concentrations for each species or variety of crop.

Finally, the efficiency of treatment with humic acids isolated from cattle manure on the initial development of indicator plants presented as an accumulation of dry matter and nutrients and also confirmed the hypothesis that new technologies could be developed based on the recycling of organic waste and isolation of bioactive humic substances (ANDRADE et al., 2011; BALDOTTO; BALDOTTO, 2013). With respect to the potential of humic acids as biostimulants, the positive effects of their treatment on the initial development of corn and the low-cost technology and low operating costs involved have rendered humic acids isolated from cattle manure as important alternatives for the treatment of corn seeds, with an aim to increase corn yield.

\section{Conclusions}

Humic acids isolated from cattle manure were found to be more bioactive than those from poultry litter, as confirmed by the growth and increase in the content of $\mathrm{N}$ and $\mathrm{P}$. This enhances the initial corn vigor and crop's yield potential.
The most effective concentrations were 23.40 mmol L-1 of $\mathrm{C}$ for humic acids extracted from cattle manure and $14.80 \mathrm{mmol} \mathrm{L}^{-1}$ of $\mathrm{C}$ for humic acids isolated from poultry litter, resulting in an increase of $45 \%$ and $16 \%$ of dry weight of the aerial part compared to the control for humic acids extracted from cattle manure and poultry litter, respectively.

\section{Acknowledgements}

The authors would like to thank CNPq, FAPEMIG, and FUNARBE for funding the projects that led to this study. We would also like to thank students, staff, and professors of the Fertilization, Nutrition, and Physiology of Plants Stimulated by Humic Substances and Growth Promoting Bacteria research group for their continuous contributions that aided in the realization of this study.

\section{References}

ALMEIDA, M. L.; MUNDSTOCK, C. M.; SANGOI, L. Conceito de ideotipo e seu uso no aumento do rendimento potencial de cereais. Ciência Rural, Santa Maria, RS, v. 28, n. 2, p. 325-332, 1998.

ALVAREZ, V. H.; ALVAREZ, G. A. M. Comparações de médias ou testes de hipóteses? Contrastes! Boletim Informativo da Sociedade Brasileira de Ciência do Solo, Viçosa, v. 31, n. 1, p. 24-34, 2006.

ANDRADE, A. F.; SILVA, R. A. F.; RIBEIRO, R. C. S. Crescimento inicial de milho (Zea mays L.) em resposta às doses de esterco bovino, fino de carvão e cinza de caldeira. 2011. Trabalho de Conclusão (Tecnologia em Gestão Ambiental) - Universidade Federal de Viçosa, Florestal.

BALDOTTO, L. E. B.; BALDOTTO, M. A.; GIRO, V. B.; CANELLAS, L. P.; OLIVARES, F. L.; BRESSANSMITH, R. Desempenho do abacaxizeiro 'Vitória' em resposta à aplicação de ácidos húmicos durante a aclimatação. Revista Brasileira de Ciência do Solo, Viçosa, MG, v. 33, n. 4, p. 979-990, 2009.

BALDOTTO, M. A.; MUNIZ, R. C.; BALDOTTO, L. E. B.; DOBBSS, L. B. Root growth of Arabidopsis thaliana (L.) Heynh. treated with humic acids isolated from typical soils of Rio de Janeiro state, Brazil. Revista Ceres, Viçosa, MG, v. 58, n. 4, p. 504-511, 2011. 
BALDOTTO, L. E. B.; BALDOTTO, M. A.; SOARES, R. R.; MARTINEZ, H. E. P.; VENEGAS, V. H. A. Adventious rooting in cuttings of croton and hibiscus in response to indol butyric acid and humic acid. Revista Ceres, Viçosa, MG, v. 59, n. 4, p. 476-483, 2012a.

BALDOTTO, M. A.; BALDOTTO, L. E. B.; GONTIJO, A. A. Composição química da compostagem de cama de aviário combinada com proporções crescentes de esterco bovino. In: FERTBIO 2012., 2012, Maceió. Anais... Maceió: FertBio, 2012b. CD-ROM.

BALDOTTO, M. A.; BALDOTTO, L. E. B. Gladiolus development in response to bulb treatment with different concentrations of humic acids. Revista Ceres. Viçosa, MG, v. 60, n. 1, p. 138-142, 2013.

BATAGLIA, O. C.; DECHEN, A. R.; SANTOS, W. R. Princípio da diagnose foliar. In: ALVAREZ V., V. H.; FONTES, L. E. F.; FONTES, M. P. F. Os solos nos grandes domínios morfológicos do Brasil e o desenvolvimento sustentável. Viçosa, MG: SBCS, UFV, DPS, 1996. 930 p.

CANELLAS, L. P.; FAÇANHA, A. R. Relationship between chemical nature of soil humifield fractions and their bioactivity. Pesquisa Agropecuária Brasileira, Brasília, v. 39, n. 8, p. 233-240, 2004.

CANELLAS, L. P.; SANTOS, G. A. Humosfera: tratado preliminar sobre a química das substâncias húmicas. Campos dos Goytacazes: UENF, 2005. 309 p.

CANELLAS, L. P.; ZANDONADI, D. B.; OLIVARES, F. L.; FAÇANHA, A. R. Efeitos fisiológicos de substâncias húmicas - o estímulo às H+-ATPases. In: FERNANDES, M. S. (Org.). Nutrição mineral de plantas. Viçosa, MG: UFV, 2006. p. 175-200.

CHEN, Y.; CLAPP, C. E.; MAGEN, H. Mechanisms of plant growth stimulation by humic substances: the role of organo-iron complexes. Soil Science and Plant Nutrition, Tokyo, v. 50, n. 7, p. 1089-1095, 2004.

COMPANHIA NACIONAL DE ABASTECIMENTO CONAB. Acompanhamento de safra brasileira: grãos, nono levantamento, Brasília: CONAB, 2013. p. 1-66.

CRUZ, J. C.; PEREIRA FILHO, I. A.; ALVARENGA, R. C.; GONTIJO NETO, M. M.; VIANA, J. H. M.; OLIVEIRA, M. F. de; SANTANA, D. P. Manejo da cultura do milho. In: CRUZ, J. C.; KARAM, D.; MONTEIRO, M. A. R.; MAGALHAES, P. C. (Ed.). $A$ cultura do milho. Sete Lagoas, MG: Embrapa Milho e Sorgo, 2008. cap. 8, p. 171-197.

EMPRESA BRASILEIRA DE PESQUISA AGROPECUÁRIA - EMBRAPA. Manejo ambiental na avicultura. Concórdia: Embrapa Suínos e Aves, 2011. $226 \mathrm{p}$.
Serviço nacional de levantamento e conservação de solos. Manual de métodos de análise de solo. Rio de Janeiro: Embrapa Solos, 1979. 282 p.

Tratamento e manejo de dejetos de bovinos. Juíz de Fora: Embrapa Gado de leite, 2001. 2 p.

EYHERAGUIBEL, B.; SILVESTRE, J.; MORARD, P. Effects of humic substances derived from organic waste enhancement on the growth and mineral nutrition of maize. Bioresourse Techonology, Amsterdam, v. 99, n. 10, p. 4206-4212, 2008.

FAÇANHA, A. R.; FAÇANHA, A. L. O.; OLIVARES, F. L.; GURIDI, F.; SANTOS, G. A.; VELLOSO, A. C. X.; RUMJANEK, V. M.; BRASIL, F.; SCHRIPSEMA, J.; BRAZ-FILHO, R.; OLIVEIRA, M. A.; CANELLAS, L. P. Bioatividade de ácidos húmicos: efeito sobre o desenvolvimento radicular e sobre a bomba de prótons da membrana plasmática. Pesquisa Agropecuária Brasileira, Brasília, v. 37, n. 9, p. 1301-1310, 2002.

GUERRA, J. C. M.; SANTOS, G. A.; SILVA, L. S.; CAMARGO, F. A. O. Macromoléculas e substâncias húmicas. In: SANTOS, G. A. (Ed.). Fundamentos da matéria orgânica do solo: ecossistemas tropicais \& subtropicais. 2. ed. Porto Alegre: Metrópole, 2008. p. 1926.

KIEHL, E. J. Manual de compostagem: maturação e qualidade do composto. 4. ed. Piracicaba: Kiehl, 2004. $173 \mathrm{p}$.

NARDI, S.; PIZZEGHELLO, D.; MUSCULO,

A.; VIANELLO, A. Physiological effects of humic substances on higher plants. Soil Biology \& Biochemistry, Amsterdam, v. 34, n. 11, p. 15271536, 2002.

PICCOLO, A. The supramolecular structure of humic substances. Soil Science, Baltimore, v. 166, n. 11, p. 810-832, 2001.

RIBEIRO, A. C.; GUIMARÃES, P. T. G.; ALVAREZ, V. Recomendação para o uso de corretivos e fertilizantes em Minas Gerais: $5^{\text {a }}$ aproximação. Viçosa: Comissão de Fertilidade do Solo do Estado de Minas Gerais, 1999. p. 46-51.

SILVA, A. C.; CANELLAS, L. P.; OLIVARES, F. L.; DOBBSS, L. B.; AGUIAR, N. O.; FRADE, D. A. R.; REZENDE, C. E.; PERES, L. E. P. Promoção do crescimento radicular de plântulas de tomateiro por substâncias húmicas isoladas de turfeiras. Revista Brasileira de Ciência do Solo, Viçosa, MG, v. 35, n. 5, p. 1609-1617, 2011. 
SILVA, R. M.; JABLONSKI, A.; SIEWERDT, L.; SILVEIRA JÚNIOR, P. Desenvolvimento do sistema radicular do azevém sob influência de diferentes fontes e dosagens de substâncias húmicas. In: REUNIÃO ANUAL DA SOCIEDADE BRASILEIRA DE ZOOTECNIA， 35., 1998, Botucatu. Anais... Botucatu: FMVZ-UNESP-SBZ, 1998a. p. 357-359.
Produção de forragem de milho: efeito de diferentes doses de substâncias húmicas no cultivo em casa de vegetação. In: REUNIÃO ANUAL DA SOCIEDADE BRASILEIRA DE ZOOTECNIA, 35., 1998, Botucatu. Anais... Botucatu: FMVZUNESP-SBZ, 1998b. p. 409-411.

SILVA, T. T. A.; PINHO, É. V. R. V.; CARDOSO, D. L.; FERREIRA, C. A.; ALVIN, P. O. Qualidade fisiológica de sementes de milho na presença de bioestimulantes. Ciência e Agrotecnologia, Lavras, v. 32, n. 3, p. 840-846, 2008. 